\title{
Language Indigenization in Terms of Language Contacts (Based on the Nigerian English Variant)
}

\author{
Jerome Baghana, Olga N. Prokhorova, Igor V. Chekulai, Tatiana G. Voloshina* and \\ Natalia A. Sheyfel
}

\author{
Belgorod State University, 308015, Belgorod, Studencheskaya Street, 14, Russia
}

\begin{abstract}
The purpose of the article is to identify the specifics of the English language Indigenization procedure on the territory of Nigeria, one of the largest countries in West Africa. The research work has the complex system to analyze the cultural and linguistic processes, which are manifested in the study under the influence of cultural factors and its influence on the language functioning. The practical work part is based on the analysis of the language thematic groups "National food" and "National clothes" presenting the specific features of Nigerian English. The results show, Nigerian English has a wide range of words denoting local realities and reflecting the adaptation of the English language to the Nigerian culture peculiarities, which are the process of indigenization. All in all, English words with new lexical meanings, words from Nigerian languages, and Portuguese loanwords have been used for naming local food and clothing elements.
\end{abstract}

Keywords: Culture, communication, language variation, Nigerian English, ethnic languages, hybrid words combinations.

\section{INTRODUCTION}

The ability of a language to influence the thinking process was firstly discovered by the American linguist and anthropologist Edward Sepir and his student Benjamin Wharf (1897-1941). According to their hypothesis, the way a person thinks and perceives the world is determined by their language (Sapir 1987; Beattie and Ellis 2017). Culture is a collection of ways and possibilities in which people live and can make sense of their existence. It is a product of the human mind and is defined, distributed and maintained through a language. The connection between language and culture is undoubtedly a symbiosis process (Obong 2019).

In the research work, culture is considered as a super-dynamic structure that aims to achieve human growth and language development. The paper examines the process of language development and its ability to influence culture.

The subject of study is the English language variant, which functions in Nigeria in conjunction with the ethnic languages' peculiarities of the tribes living in modern Nigeria. Although these languages are the basis of ethnic, regional, and national identity (Nwegbu et al. 2011; Sung 2016; Zulaikha and Purwaningsih 2019). The article deals with the analyses of language situation's peculiarities in Nigeria, with the English

*Address correspondence to this author at the Belgorod State University, 308015, Belgorod, Studencheskaya Street, 14, Russia;

E-mail: baghana@yandex.ru language domination process in various spheres of life: education, economy, politics, mass media (Smokotin et al. 2017; 2019). The factors contributing to the ground of Nigerian English formation are closely connected with cultural peculiarities Nigerian. The authors stress, the Nigerian English variant is the hybrid mixture of a formation based on the syntax, vocabulary, and phonetics of the English language, supplemented by elements of Nigerian ethnic languages' cultural groups (Ajepe and Ademowo 2016; Iwuchukwu and Okafor 2017; Jerome and Voloshina 2019). The practical work part is based on the analysis of the language thematic groups "National food" and "National clothes" presenting the specific features of Nigerian English.

\section{Objectives}

The purpose of the article is to identify the specifics of the English language Indigenization procedure on the territory of Nigeria, one of the largest countries in West Africa. The research work has the complex system to analyze the cultural and linguistic processes, which are manifested in the study under the influence of cultural factors and its influence on the language functioning

\section{METHODOLOGY}

This article is based on the systemic approach to the interdisciplinary analysis. Due the cognitive crossdisciplinary approach we take into consideration the anthropocentric factor, linguistic and non-linguistic information, intercultural analyses, especially dealing with the problem of mentality and language correlation. The research work has the complex system to analyze 
the cultural and linguistic processes, which are manifested in the study under the influence of cultural factors and its influence on the language functioning. The article deals with the analyses of language situation's peculiarities in Nigeria, with the English language domination process in various spheres of life: education, economy, politics, mass media. The factors contributing to the ground of Nigerian English formation are closely connected with cultural peculiarities Nigerian.

\section{RESULTS}

Culture reflects the way of people's lives, their customs, traditions, ideas, values, which are embodied in different forms, including a language. A language has the ability to interact with another culture. Thus, the history of the English language began with the contacts of the Anglo-Saxons with the Romans and the French, which is reflected, for example, in the vocabulary (today $80 \%$ of "culinary" expressions in English have a French origin, and most of the words of the English language contain Latin roots (Ifemesia 2001; Nwanyanwu 2017). The relationship between English and Nigerian culture has a similar history: many English loanwords have been integrated into Nigerian languages.

In Nigeria, being a part of the national education policy, English has been adopted as the standard for successful education and social development, and this also depends on the influence of the language as an international language used for all official and educational purposes. Today, English is also the main language of legislation used in both the National and State Assemblies. Currently, in every family, including semi-literate ones, children's knowledge of English begins in the process of visiting primary education level of state schools (Banjo 1971).

The influence of English on the culture of modern Nigeria is extremely high. Many Nigerian linguists are alarmed by its dominant influence on the culture of Nigeria. However, it is impossible to discuss the specifics of the concept of Nigerian English without taking into account the Nigerian cultural influence on the structure of the English language. In modern Nigerian linguistics, it is customary to distinguish several varieties of Nigerian English variants. According to linguist Ayo Banjo, the most widely used is the syntactic, lexical and phonetic system that maximum corresponds to Standard British English (Banjo 1971; Reyes, et al., 2016).
Another distinctive feature of the language situation in Nigeria is the significant influence of Americanisms especially being used by Nigerian students. This is facilitated by globalization, which happens due to broad technological and electronic communication between speakers of different cultures. The mutual influence of Nigerian culture and the English language led to the emergence of such a concept as Nigerian English. At the same time, knowledge of Nigerian languages is a part of the Nigerian culture. A Nigerian citizen who cannot speak his native language is not considered a successful personality. Nigeria is a multilingual state with more than five hundred ethnic languages: Hausa, Igbo, Yoruba, Ibibio, Fulani, Edo, Kaniru, Efik, Fulfulde, and several hundred others. Moreover, many ethnic groups communicate within their community using their own dialects, while activities involving different ethnic groups discussions are carried out in English (Kachru 1992)

There is a number of features of interaction between culture and language when activating the thought process in the mind of a Nigerian. Native speakers must have the ability to manipulate their language for effective thinking. Nigerian culture that finds expression in a foreign language, whether in oral or written form, is also an endangered species, as any culture without its own language faces problems interpreting its meaning. At the present stage of development of the Nigerian society, it is obvious that the development of indigenous languages is becoming the most acute problem that requires immediate solution by the Nigerian authorities, otherwise the problem of extinction of the native language, which accompanies the process of culture loss, may arise in the nearest future.

According to Nigeria's language education policy, a child must be taught in the local language school during the first three years, and English must be taught as a subject of general education process. Further, starting from the fourth grade of Primary Education period, English should serve as a way of instructions for all subjects, and the indigenous language (Igbo, Hausa or Yoruba) will be taught as a regular subject.

Describing indigenization on the territory of Nigeria, it should be noted that the influence of local trends on cultural isolation can be considered as an adaptation and some restriction of the English. To refer to this phenomenon, according to Adegbija's research, the term indigenization can be used, since English in Nigeria has been adapted for local needs and has 
become applicable to experiences, nuances, and feelings of Nigerians (Adegbija 2008; Obiegbu 2016).

The process of indigenization in Nigeria leads to the development of an internal norm, as evidenced by the fact that the speech practice of Nigerians uses numerous structures that are incomprehensible to native English speakers. Some scholars denied the existence of Nigerian English variant and attributed the peculiarities of English in Nigeria to deviations from Standard British English. However, many well-known scholars, such as Adegbija and Banjo, claim that Nigerian English exists and does have numerous social subtypes. Nigerian linguists of the XXI century, Awonusi and Egbe, offered a description of the nature and character of the Nigerian English language. The famous linguist Igboanusi created a series of linguistic dictionaries of the territorial version of the Nigeria English variant, which reflect the phonetic, lexical, semantic features of the Nigerian English language together with the cultural specifics. Such works, according to Adegbia, undoubtedly show the adaptation of the English language to Nigeria reality, this process has come a long way (Adegbija 2008; Obiegbu 2016; Varghese, 2016).

It is well-known, that the meanings of words are closely related to the mental representations existing in native speakers' understanding. High-quality translations of lexical units are aimed at creating the same effect in the translation as in the original text. For example, the word bread evokes different mental images in the minds of people from different cultures, depending on whether they are, for example, European or African. According to the French, bread has the understanding of a country bread, - baguette or brioche; moreover different types of bread are used with different dishes and at different time of the day (breakfast, lunch, dinner). According to the views of Africans, in particular Nigerians, bread has one way of understanding, but it can be of different forms: whole or cut into pieces. Bread is eaten at any time of the day and with many dishes and drinks.

The features of this phenomenon, such as the indigenization of the territorial version of the English language, are revealed in our research at the lexical level, namely in the aspect of semantic and etymological characteristics of the thematic groups "National food" and "National clothes".

The theme group "National food" is a wide range of lexical units that convey the cultural diversity of
Nigerian ethnic groups. In Africa, local cuisine is special in every country and for every nation. Daily Nigerian national food is a unique combination of traditions and customs of many nationalities of West African countries. A Nigerian's lunch or dinner usually consists of two components: a side dish and a main course (vegetables and meat or fish in a sauce).

The side dish is an unleavened dish that is usually prepared from yam flour (Yam is a tuber that resembles potatoes in shape and taste). Yam garnish can be compared with mashed potatoes, it has a porridge-like consistency, may be white or brown. In the Nigerian language, it is called yam or pounded yam. The best, and therefore most expensive variety of yam has a white color, this type of product is called Abuja yam. Another variety of yam has a brown color and is called Amala (àmàlà) yam. Amale is thoroughly dried when cooking, so it gets this color.

Another essential component of the cuisine of West Africa and in particular Nigeria is cassava, a product that is of a starchy substance extracted from the tubers of the powdery cassava plant. Its shape and taste resembles yam, but has a much smaller size. Cassava flour is called garri, and it is often used to make a porridge-like side dish called eba.

Rice in Nigeria is a typical dish of the national cuisine. A particularly famous local rice variety is ofada, which is used to prepare a stew called ofada stew. Ofada rice is an expensive product, therefore it is eaten in small quantities and most often on holidays and on special occasions. An example of a festive rice dish is the national dish of Nigeria is jollof rice, it is rice cooked with tomatoes and spices, served with chunks of meat at parties (Blench and Dendo 2005).

A dish that complements are amale, ebe or ofade in Nigerian cuisine is always a special spicy dish (Nigerian cuisine is significantly sharper than, for example, the cuisine of Ethiopia or Ghana). The main dish has an international name soup, but Nigerian soup is usually much thicker than Russian or French soup. To achieve this thickness a special product is used in preparing the soup, which is called achi - a powder-like substance used for soup thickening (Epstein and Kole 1998).

The method of cooking Nigerian soup is its long stewing, in contrast to the Russian method of cooking soup - boiling. At the same time, it should be noted that soup and stew have differences in Nigerian cuisine. 
Leaves or herbs are usually added to the Nigerian soup, but not to the stew.

There are many varieties of soups in the national cuisine of Nigeria, while significant differences are determined by the local affiliation of a particular national cuisine: to the Northern, Western or Southern parts of the region. The soup can be made from various combinations of vegetables and types of fish and meat, for example: Congo Meat soup - soup made from giant African snails; Crayfish soup - shrimp soup; Cowleg soup - veal soup; Croaker - sea fish soup; Grasseater -fish soup; Pepper soup - soup with meat or fish, which includes chili pepper and does not require oil for cooking; Peprish soup - pepper soup (Blench and Dendo 2005). A specific feature of English in Nigeria is the choice of the verb used to express the process of eating soup, which is to drink soup.

English in Nigeria is characterized by using some names of dishes from the Portuguese language, one of them is Farina - dry food prepared from cassava.

We must mention, in Nigerian English there are many lexemes of the thematic group "National food", belonging to Nigerian ethnic languages, for example:

from Hausa languages:

grasseater - fish soup; kose - fried pancakes; kunnu - sugar and ginger drink made from cereals, sugar and ginger, which is widely distributed in the Northern part of Nigeria (Blench and Dendo 2005);

- $\quad$ from Yoruba languages:

eba - main dish made from boiled cassava, the product is cheaper than yams; eko - cooked cassava food; egusi - melon, or dried seeds used for making sauce); Amala - brown product made from sweet potatoes assorted - stew of different parts of meat that is usually served in restaurants (Epstein and Kole 1998);

- $\quad$ from lgbo languages:

agidi - a dish of creamy consistency made from corn; akpu - mashed cassava; alligator pepper a special device with which to prick nuts (Epstein and Kole 1998).

The theme group "National clothes" in Nigerian English is exclusively original and the language contains lexical units of indigenous languages to describe certain realities of culture. Traditions of making and wearing clothing in Nigeria are very diverse, some traditional outfits go back to ancient tribes lived on this territory centuries ago, others were formed under the influence of British, Portuguese and French colonizers during XIX-XX centuries. Today, many Nigerians use modern clothing, preferring the Western style, but still there are many who wear traditional clothing. Nigeria's national dress reflects local trends in cultural identity and its independence.

Nigeria is home to several ethnic groups, the largest of which are the Yoruba, Igbo, and Hausa-Fulani, each of which has its own national dress.

For the Yoruba people, bright colors in the wardrobe are typical, especially when clothing is intended for special occasions such as weddings and funerals. There is the reason to believe that the national dress of the Yoruba people is a traditional costume for Nigeria as a whole. Partly this opinion was formed due to the popularity and predominance of bright colors such as yellow, green and red. For ethnic Yoruba clothing, there are many examples that are the part of Nigerian English:

- adire - colorful clothing worn by men and women;

- $\quad$ buba - casual blouse with a round or V- neck and long sleeves, its length is slightly below the waist, this type of clothing is acceptable for both men and women;

- $\quad$ iro - a men's robe that is worn over the other clothes, it is used for formal events;

- $\quad$ sokotos - loose trousers with a drawstring at the waist;

- $\quad$ gele - traditional Nigerian headdress that is used by women;

- $\quad$ aso ebi - a certain type of clothing that is usually worn by relatives or friends on special occasions;

- $\quad$ aso oke - a special type of clothing worn by both men and women to participate in important ceremonies such as weddings, funerals and other important events (Epstein and Kole 1998).

Traditional women's attire for Igbo women are various variations of capes: capes for everyday life, 
made of coarse fabrics, and capes for official occasions, sewn from imported fabric, with patterns and various decorations. National clothing for Igbo men consists of cotton capes, shirts and sandals. Capes for everyday use are made from cheap fabrics, and clothes for holidays and special events are made from higher-quality fabrics.

Igbo daily wardrobe clothing has the following example:

agbada - a bright dress worn by men and women;

akwete - a special type of clothing with embroidery produced in Akwete town and used by Igbo people (Epstein and Kole 1998).

Men's traditional Hausa attire consists of a widesleeved robe - babban riga - which is a floor-length garment with long, wide sleeves. This clothing is similar to the agbada clothing of the Yoruba. This men's dress is popular among Nigerian men as clothing for official events. Hausa men also wear the Fula headdress, which is a round cap. Traditional women's Hausa attire consists of colorful abaia capes, which are complemented by matching blouses (Voloshina 2019).

Some items of clothes of the Yoruba, Igbo, Hausa and other peoples of Nigeria became traditional for the whole country, for example, for the Buba, Sokoto, and Fule peoples. In general, Nigerian national clothing is bright in colors, often in the process of creating it Nigerians use handmade jewelry made from natural materials: glass, stones, wood, ceramics, and wear them in large quantities.

Thus, the trends of indigenization in Nigeria reflect the features of the current state of its linguistic culture. The thematic groups "National food" and "National clothes" reflect the peculiarities of lexical units' representation that combines the equivalents of both British English and the languages of the indigenous peoples of Nigeria. Lexical units of the English language are adapted to the linguistic and cultural realities of the Nigerian language and acquire new components of lexical meaning which is the process of English indigenization to needs of local cultures.

\section{CONCLUSION}

To sum it all, language and culture are hypersensitive entities that can adapt to different living conditions. In Nigeria, the result of this adaptation of the English language to a multi-ethnic linguistic culture of Nigeria was the formation of the Nigerian English language. It is a hybrid substance based on the phonetics, vocabulary, and grammar of British English norms, and combines linguistic markers of indigenous languages. As a result of this interaction, Nigerian English was the subject to indigenization, which manifested itself primarily in the lexical system. Thematic groups of vocabulary that reflect the cultural realities of multi-ethnic Nigeria, such as "National food" and "National clothes", are characterized by heterogeneity, since they include English words that develop new lexical meanings, words from the languages of Nigerian peoples, as well as Portuguese loanwords.

\section{RECOMMENDATIONS}

It is suggested that this study be considered for other countries on the African continent, as well as for other cultural and linguistic dimensions in these countries, so that the issue in these dimensions can be fully explored in different dimensions.

\section{REFERENCES}

Adegbija, A. (2008). Features of language use in Yoruba traditional language. Ibadan, University of Ibadan. African University Press. Nigeria.

Ajepe, I., \& Ademowo, A.J. (2016). English language dominance and the fate of indigenous languages in Nigeria. International Journal of History and Cultural Studies, 2(4), 2454-7654. https://doi.org/10.20431/2454-7654.0204002

Banjo, A. (1971). Towards a definition of Standard Nigerian English Spoken English, 2(3), 165-175.

Beattie, G., Ellis, A.W. (2017). The psychology of language and communication. Taylor \& Francis. Abingdon, United Kingdom. https://doi.org/10.4324/9781315187198

Blench, R., Dendo, M. (2005). A dictionary of Nigerian EnglishCambridge, United Kingdom, CB1 2AL. 15-26.

Epstein, E.L., \& Kole, R. (1998). The language of African literature. Africa World Press. 45-56. Trenton, USA.

Ifemesia, C. (2001). The place of local languages in Nigeria today. Nigerian languages and cultural development. Lagos: The National Language Centre, Federal Ministry of Education. Ibadan: Mosuro Publishers. Nigeria.

Iwuchukwu, G.C., Okafor, M. (2017). Nigerian Pidgin in the 21st Century: Any Hope of surviving the Opposition from English, Nigerian Languages and Foreign Languages? Advances in Social Sciences Research Journal, 4(11). 10-17. https://doi.org/10.14738/assri.411.3070

Jerome, B., Voloshina, T.G. (2019). The impact of english on the linguistic and cultural status of the indigenous languages of nigeria. Humanitarian Research, 3(1), 5-11.

Kachru, B.B. (1992). World Englishes: Approaches, issues and resources. Language teaching, 25(1), 1-14. https://doi.org/10.1017/S0261444800006583

Nwanyanwu, A.U. (2017). The Place of Indigenous Languages in Sustainable National Development in the twenty-first Century: The Nigerian Perspective. International Journal of English Language and Communication Studies, 3(3), 1-5. 
Nwegbu, M.U., Eze, C.C., Asogwa, B.E. (2011). Globalization of cultural heritage: issues, impacts, and inevitable challenges for Nigeria. Library Philosophy and Practice, 1(1), 32-37.

Obiegbu, I. (2016). Language and culture: Nigerian perspective. African Research Review, 10(4), 69-82. https://doi.org/10.4314/afrrev.v10i4.5

Obong, U. (2019). Television and Nigerian Cultural Values: The Symbiosis and Social Impacts. Equatorial Journal of Communication Technology, 2(1), 9-19.

Reyes, N. S., Santamaria, H. S., \& Garcia, M. R. (2016). Proposed methodology for learning english with the use of TICs. Case: Universidad Tecnológica Equinoccial. Journal of Information Systems Engineering \& Management, 1(4), 47. https://doi.org/10.20897/lectito.201647

Sapir, E. (1987). Communication. The Psychology of Language, Thought and Instruction. Taylor \& Francis, P.46. Abingdon, United Kingdom.

Smokotin, V.M., Petrova, G.I., Gural, S.K. (2017). Teaching and learning English as the global language in the education systems of the globalized world. Language and Culture, 10(1), 10-18.

https://doi.org/10.17223/24109266/10/9
Smokotin, V.M., Petrova, G.I., Gural, S.K. (2019). The linguistic situation in Sub-Saharan Africa in the postcolonial period and the problems of linguistic decolonization. Language and Culture, 13(1), 25-36.

https://doi.org/10.17223/24109266/13/5

Sung, C.C.M. (2016). Exposure to multiple accents of English in the English Language Teaching classroom: from second language learners' perspectives. Innovation in Language Learning and Teaching, 10(3), 190-205. https://doi.org/10.1080/17501229.2014.936869

Varghese, D. T. (2016). Omani women and their happiness: an exploratory study based on gnh and swls tool. Humanities \& Social Sciences Reviews, 4(1), 01-07. https://doi.org/10.18510/hssr.2016.411

Voloshina, T.G. (2019). Features of English Language Indigenization in Nigeria. Vestnik Volgogradskogo Gosudarstvennogo Universiteta. Seriía'2, IAżykoznanie, 18(2), 65-75.

Zulaikha, F.I., Purwaningsih, S. (2019). Man made language in sundanese proverb: lingua and sociocultural analysis of male dominated construction. In UNNES International Conference on ELTLT, 19(1), 49-57.

DOI: https://doi.org/10.6000/1929-4409.2020.09.131

(C) 2020 Baghana et al.; Licensee Lifescience Global.

This is an open access article licensed under the terms of the Creative Commons Attribution Non-Commercial License (http://creativecommons.org/licenses/by-nc/3.0/) which permits unrestricted, non-commercial use, distribution and reproduction in any medium, provided the work is properly cited. 